University of Nebraska - Lincoln

DigitalCommons@University of Nebraska - Lincoln

Transactions of the Nebraska Academy of Sciences and Affiliated Societies

Nebraska Academy of Sciences

3-25-2021

\title{
Lined Snake (Tropidoclonion lineatum) Prescribed Fire Mortality
}

Carson Schultz

Platte River Whooping Crane Maintenance Trust, cschultz1440@gmail.com

Andrew J. Caven

Platte River Whooping Crane Maintenance Trust

Follow this and additional works at: https://digitalcommons.unl.edu/tnas

Part of the Life Sciences Commons

Schultz, Carson and Caven, Andrew J., "Lined Snake (Tropidoclonion lineatum) Prescribed Fire Mortality" (2021). Transactions of the Nebraska Academy of Sciences and Affiliated Societies. 530.

https://digitalcommons.unl.edu/tnas/530

This Article is brought to you for free and open access by the Nebraska Academy of Sciences at DigitalCommons@University of Nebraska - Lincoln. It has been accepted for inclusion in Transactions of the Nebraska Academy of Sciences and Affiliated Societies by an authorized administrator of DigitalCommons@University of Nebraska - Lincoln. 


\title{
Lined Snake (Tropidoclonion lineatum) prescribed fire mortality
}

\author{
Carson Schultz and Andrew Caven \\ Platte River Whooping Crane Maintenance Trust, Wood River, NE, 68883, USA \\ Corresponding author: Carson Schultz; 308-258-0265; email: cschultz1440@gmail.com
}

\begin{abstract}
Functioning prairie ecosystems are characterized by periodic and cyclical disturbances (e.g., grazing, drought, fire, etc.). Grazing and fire were historically widespread drivers of habitat structure. Many native species are adapted to fire and rely on the diverse habitats it maintains in a range of successional states. Wildlife mortality is an inevitable result of many prescribed fires and various species of small terrestrial vertebrates with limited dispersal abilities are most commonly affected. Herein, we report on the detected mortality of an individual Lined Snake (Tropidoclonion lineatum) after a prescribed burn along a lowland tallgrass prairie wet meadow ecotone in South Central Nebraska. Little information exists on this topic as our record is only the second published observation of T. lineatum mortality resulting from a prescribed burn to our knowledge. Land managers can limit the negative impacts of prescribed fire on native species of conservation concern by considering their natural histories during the planning process.
\end{abstract}

Keywords: Lined Snake, Tropidoclonion lineatum, herpetofauna, prescribed fire, incidental mortality, Nebraska, Platte River, land management, wet meadow, lowland tallgrass prairie

DOI: $10.32873 /$ unl.dc.tnas.41.3

Prairie ecosystems of the Great Plains are characterized by cyclical disturbances (Anderson 2006). Before anthropogenic forces altered the landscape, grazing by ungulates and periodic fires were major drivers of habitat structure that created patchy habitats in various stages of succession (Anderson 2006, Fuhlendorf et al. 2009). Many native species are adapted to fire and rely on the diverse habitat types it creates throughout important stages of their life cycles (e.g., Caven et al. 2017, Glass et al. 2020). Some wildlife mortality is an inevitable result of many prescribed fires. Small and less mobile vertebrates such as reptiles and amphibians are the most likely to exhibit panic and experience higher rates of mortality relative to other small taxa (Lyons et al. 1978). The direct mortality of herpetofauna from prescribed fire in the Great Plains remains understudied (Pilliod et al. 2003). Land managers can utilize this information and implement regimes that reduce the negative effects of prescribed fire on species of conservation concern. Herein, we report on the detected mortality of an individual Lined Snake (Tropidoclonion lineatum) after a growing season burn in the Central Platte River Valley (CPRV), Nebraska. Tropidoclonion lineatum is not listed as a species of concern in $\mathrm{Ne}-$ braska, but is listed as endangered at the state-level in neighboring South Dakota, and has experienced regional declines within its range (SD GFP 2014).

On 19 August 2020, a deceased T. lineatum was found in the ashes following a 14-ha prescribed fire in the CPRV on Shoemaker Island, Hall County, Nebraska, USA ( $40.77399^{\circ} \mathrm{N}, 98.50068^{\circ} \mathrm{W}$, WGS 84; $568 \mathrm{~m}$ elev.). The 57-ha parcel included 48 ha of herbaceous habitat that had been managed for hay for several decades prior to the burn, which was intended to promote floral diversity. The vegetation community was dominated by lowland tallgrass prairie including Andropogon gerardii (Big Bluestem), Sorghastrum nutans (Indian Grass) and Bromus inermis (Smooth Brome) with intermixed forbs such as Asclepias verticillata (Whorled Milkweed), Apocynum cannabinum (Hemp Dogbane), and Solanum carolinense (Carolina Horsenettle; Currier 1989, Henszey et al. 2004, Kaul et al. 2006). Lower-lying portions of the parcel supported wet meadow habitat including Schoenoplectus pungens (Common Three-Square), Carex spp. (Sedges), and Vernonia fasciculata (Prairie Ironweed; Currier 1989, Henszey et al. 2004). A riparian woodland located $50 \mathrm{~m}$ to the north included mature Populus deltoides (Plains Cottonwood) and Juniperus virginiana (Eastern Red Cedar), with an understory dominated by Cornus drummondii (Roughleaf 


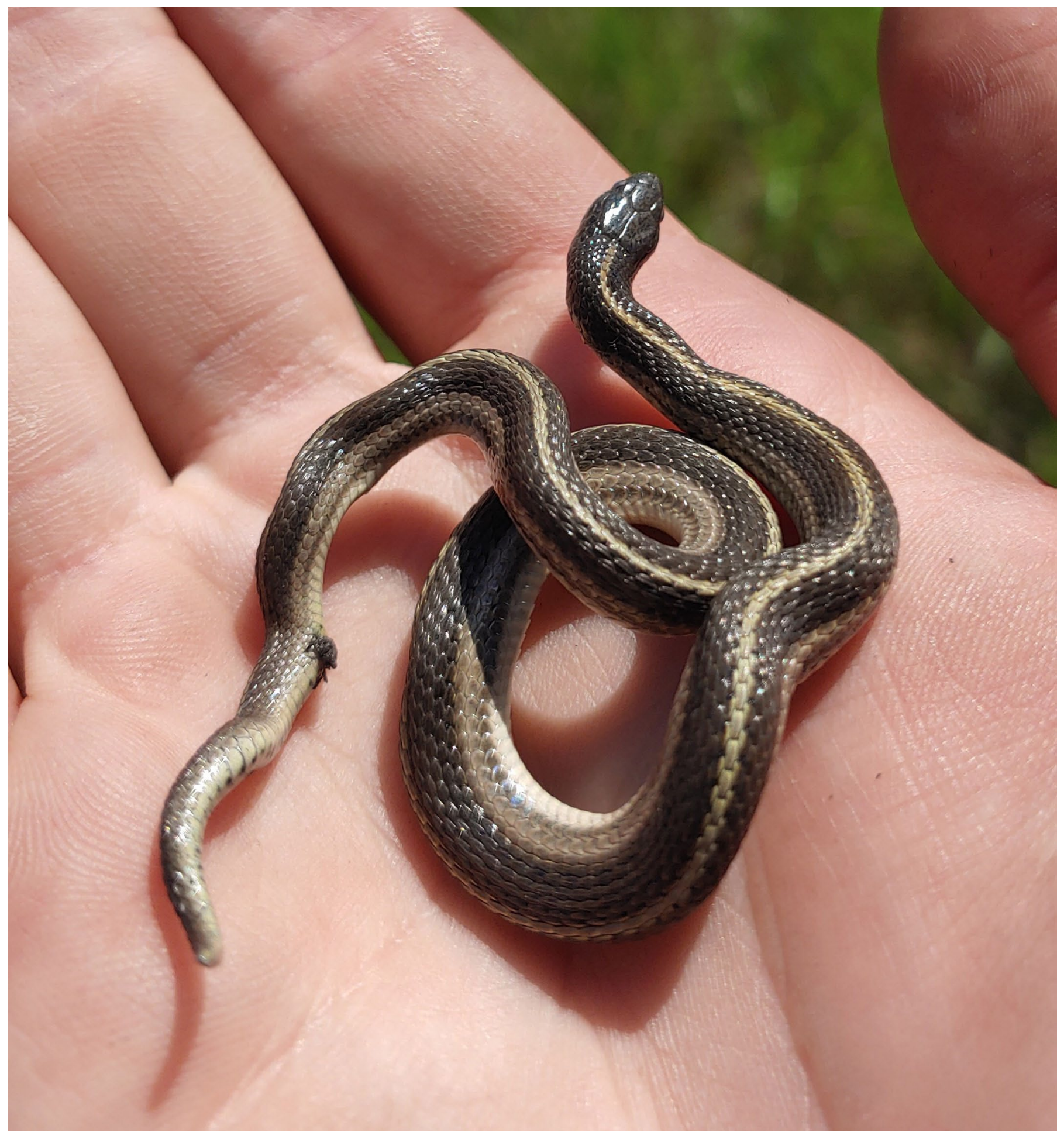

Figure 1. Deceased Tropidoclonion lineatum (Lined Snake) with exerted hemipenes near the Platte River, Hall County Nebraska, 19 August 2020.

Dogwood; Kaul et al. 2006). The site has Platte-Bolent complex soils that are occasionally flooded (USDA-NRCS 2020). The snake was found $225 \mathrm{~m}$ from the nearest gravel road, $660 \mathrm{~m}$ from a paved highway, and $460 \mathrm{~m}$ from the main channel of the Platte River. The controlled burn began as a backing fire at 13:40 $\mathrm{h}$, by 15:10 $\mathrm{h}$ the perimeter of the burn unit had been completely ignited (flank and head fires), and the majority of fuels were consumed by 
16:00 h. Ambient temperatures ranged from 26 to $29^{\circ} \mathrm{C}$, relative humidity from 53 to $57 \%$, and winds from 6 to 16 $\mathrm{kph}$ during the controlled burn. The backing fire moved at an estimated rate of $0.5 \mathrm{~m}$ per minute and the head fire at $6 \mathrm{~m}$ per minute. Flame heights from the head fire averaged about $0.6 \mathrm{~m}$ and reached $1 \mathrm{~m}$ in densely vegetated areas. The burn left sparse green areas and some unburned litter.

Upon checking the perimeter of the fire, burn crew members detected a recently deceased adult male T. lineatum with its hemipenes exerted and hardened (Total length $=22.25 \mathrm{~cm}$; Figure 1). Previous studies have shown physical stress and trauma to cause hemipenes to become exerted in wild snakes (Pernetta and Reading 2009). It is possible the hemipenes on this individual were exerted as a result of heat and stress from the fire prior to death. The snake was found $1 \mathrm{~m}$ from the northern fire boundary where the backing fire was initially ignited. This is only the second published observation of a T. lineatum mortality resulting from prescribed fire to our knowledge. The other recorded mortality was noted after an early growing season (May 5) fire in similar lowland tallgrass prairie habitat $26 \mathrm{~km}$ west of this location along the Platte River (O'Connor et al. 2016). This fossorial species spends most of its active season underground, especially during the warmest months and is substantially more visible in the spring and fall (Fogell 2010). Though this burn took place in the late summer, temperatures were relatively mild and may have been associated with $T$. lineatum above-ground activity.

It is notable that we observed this mortality in regard to a relatively slow-moving, low intensity, and patchy fire, suggesting even mild fire behavior can impact some snake species. Implementing controlled burns on a portion of habitat and maintaining unburned refugia can limit negative impacts on isolated metapopulations of prairie herpetofauna with limited dispersal abilities (Setser and Cavitt 2003). We likely restricted our impacts on T. lineatum by burning only $30 \%$ of the lowland tallgrass prairie and wet meadow present at this site. A variable fire regime with burns across multiple seasons over time may be necessary to maximize grassland biodiversity (Knapp et al. 2009). However, controlled burn regimes can often be temporally targeted to reduce negative impacts on native species of concern during their active periods or critical life stages while also meeting most management objectives (Pilliod et al. 2003).

\section{Acknowledgments}

We thank The Nature Conservancy for access to the land and in particular Chris Helzer for providing data regarding fire behavior. We also thank the Crane Trust for funding and use of equipment as well as Johanna DeStefano for supporting this research through the Lila O. Wilson Biological Monitoring Internship.

\section{Literature Cited}

Anderson RC. (2006) "Evolution and origin of the Central Grassland of North America: climate, fire, and mammalian grazers." The Journal of the Torrey Botanical Society 133(4):626-647.

Caven AJ, King KC, Wiese JD, and Brinley Buckley EM. (2017) "A descriptive analysis of Regal Fritillary (Speyeria idalia) habitat utilizing biological monitoring data along the Big Bend of the Platte River, NE." Journal of Insect Conservation 21:183.

Currier PJ. (1989) "Plant species composition and groundwater levels in a Platte River wet meadow." Proceedings of the North American Prairie Conference 11:19-24.

Fogell DD. (2010) A Field Guide to the Amphibians and Reptiles of Nebraska. Institute of Agriculture and Natural Resources, University of Nebraska-Lincoln. 138 pp.

Fuhlendorf SD, Engle DM, Kerby J, and Hamilton R. (2009) Pyric herbivory: rewilding landscapes through the recoupling of fire and grazing. Conservation Biology 23: 588-598.

Glass, AJ, Caven AJ, Kim D, Sutton MO, and Arcilla N. (2020) "Climate change and land management implications for a declining Neotropical migratory songbird breeding in the North American Great Plains." Avian Conservation and Ecology 15 (1):4.

Henszey RJ, Pfeiffer K, and Keough JR. (2004) “Linking surface- and ground-water levels to riparian grassland species along the Platte River in central Nebraska, USA." Wetlands 24:665-687.

Kaul RB, Sutherland S, and Rolfsmeier S. 2006. The flora of Nebraska. School of Natural Resources, University of Nebraska-Lincoln, Lincoln, NE.

Lyon LJ, HS Crawford, E Czuhai, RL Fredriksen, RE Harlow, LJ Metz, and HA Pearson. (1978) Effects of fire on fauna: a state-of-knowledge review. United States Department of Agriculture Forest Service.

Knapp EE, Estes BL, and Skinner CN. (2009). Ecological effects of prescribed fire season: a literature review and synthesis for managers. JFSP Synthesis Reports. 4.

O'Connor BJ, Forrester AJ, and Geluso K. (2016). Tropidoclonion lineatum (Lined Snake). Fire mortality. Herpetological Review, 47(3). 
Pernetta A. (2009). Coronella austriaca (smooth snake) paraphimosis. Herpetological Review, 40(95).

Pilliod DS, Bury RB, Hyde EJ, Pearl CA, Corn PS. 2003. “Fire and amphibians in North America." Forest Ecology and Management 178:163-181.

Setser K, and Cavitt JF. (2003). Effects of burning on snakes in Kansas, USA, tallgrass prairie. Natural Areas Journal, 23(4), 315-319.
South Dakota Department of Game, Fish and Parks (SD GFP). 2014. South Dakota Wildlife Action Plan. Wildlife Division, South Dakota Department of Game, Fish and Parks, Pierre, SD, USA.

USDA-NRCS, United States Department of AgricultureNatural Resources Conservation Service, Soil Survey Division. (2020) Web Soil Survey. Retrieved from the Internet 20 September 2020: http:// websoilsurey.nrcs. usda.gov/ 